\title{
WHO MOVES TO MIXED-INCOME NEIGHBORHOODS?
}

by

\author{
Terra McKinnish * \\ University of Colorado
}

and

T. Kirk White *

Economic Research Service, U.S. Department of Agriculture

CES 10-18 August, 2010

The research program of the Center for Economic Studies (CES) produces a wide range of economic analyses to improve the statistical programs of the U.S. Census Bureau. Many of these analyses take the form of CES research papers. The papers have not undergone the review accorded Census Bureau publications and no endorsement should be inferred. Any opinions and conclusions expressed herein are those of the author(s) and do not necessarily represent the views of the U.S. Census Bureau. All results have been reviewed to ensure that no confidential information is disclosed. Republication in whole or part must be cleared with the authors.

To obtain information about the series, see www.ces.census.gov or contact Cheryl Grim, Editor, Discussion Papers, U.S. Census Bureau, Center for Economic Studies 2K130B, 4600 Silver Hill Road, Washington, DC 20233, CES.Papers.List@census.gov. 


\begin{abstract}
This paper uses confidential Census data, specifically the 1990 and 2000 Census Long Form data, to study the income dispersion of recent cohorts of migrants to mixed-income neighborhoods. If recent in-migrants to mixed-income neighborhoods exhibit high levels of income heterogeneity, this is consistent with stable mixed-income neighborhoods. If, however, mixed-income neighborhoods are comprised of older homogenous lower-income (higher income) cohorts combined with newer homogenous higher-income (lower-income) cohorts, this is consistent with neighborhood transition. Our results indicate that neighborhoods with high levels of income dispersion do in fact attract a much more heterogeneous set of in-migrants, particularly from the tails of the income distribution, but that income heterogeneity does tend to erode over time. Our results also suggest that the residents of mixed-income neighborhoods may be less heterogeneous with respect to lifetime income.

* The research in this paper was conducted while the authors were Special Sworn Status researchers of the U.S. Census Bureau at the Triangle Census Research Data Center. Any results and conclusions expressed herein are those of the authors and do not necessarily represent the views of the Census Bureau or of the Department of Agriculture. All results have been reviewed to ensure that no confidential information is disclosed. Helpful comments from Francisca Antman, Jeffrey Zax and Charles de Bartolome are gratefully acknowledged. We would like to thank Monica Wood for valuable research assistance and Randall Walsh for graciously allowing us to use his linking of 1990 and 2000 Census tracts. This research was supported by Grant Number R0HD053860 from the National Institute of Child Health and Human Development. Its contents are solely the responsibility of the authors and do not necessarily represent the official views of the National Institute of Child Health and Human Development. Finally, support for this research at the Triangle Census Research Data Center from NSF (ITR-0427889) is also gratefully acknowledged.
\end{abstract}




\section{Introduction}

Do neighborhoods with high levels of income dispersion attract economically diverse inmigrants? Or, alternatively, are these neighborhoods simply in transition, so that the income dispersion results from the fact that recent in-migrants are either higher or lower-income than longer-term residents? This paper analyzes the income dispersion of recent migrants to mixedincome neighborhoods in order to better understand the processes of economic segregation and neighborhood sorting in U.S. urban areas.

There is a sizeable literature measuring economic segregation of U.S. households by neighborhood (Massey and Eggers, 1990; Jargowsky, 1996; Mayer, 2001; Massey and Fischer, 2003; Fischer, 2003; Hardman and Ioannides, 2004; Jargowsky and Yang, 2006). Much of this literature is motivated by an interest in the concentration of poverty. Researchers point out that the degree of economic integration at the neighborhood level can exacerbate or buffer individuallevel income inequality by determining the extent to which low-income households experience neighborhoods with a lower tax base, lower levels of public amenities, and reduced access to employment networks (Massey and Fischer, 2003).

Additionally, there is also a general interest in how households sort across neighborhoods. Standard economic approaches predict that households will generally sort by income into very homogenous neighborhoods (Tiebout, 1956; Alonso, 1964; Schelling, 1969). The general finding in the literature is that while economic segregation has increased over time, there remains a substantial degree of income heterogeneity at the neighborhood level, much more than observed with respect to racial segregation (Farley, 1977; Massey and Fischer, 2003;

Fischer, 2003). Contrary to the predictions of basic economic theory, a very large fraction of the 
variation in household income within metropolitan areas is within-neighborhood variation compared to between-neighborhood variation (Farley, 1977; Jargowsky, 1996; Mayer, 2001). ${ }^{1}$ While the vast majority of work on neighborhood-level income heterogeneity is crosssectional, two recent studies by Krupka (2008) and Tach (2009) explore the stability of mixedincome neighborhoods over time. Using data linking Census tracts or block groups over time, both papers explore the extent to which mixed-income neighborhoods in one Census remain mixed-income neighborhoods in the following Census. As Krupka (2008) points out, observing mixed-income neighborhoods in a single-cross section could reflect the fact that these neighborhoods are in the process of transitioning, for example from a lower-income to a higherincome neighborhood, and therefore temporarily contain a mix of longer-term lower-income residents and newer high-income residents. Distinguishing whether the mixed-income neighborhoods observed in a cross-section are stable or transitioning has important implications for both the standard of living of low and middle class households as well as for theoretical models of neighborhood sorting.

This paper takes a new approach to the analysis of neighborhood income heterogeneity by studying the income dispersion of recent migrants to neighborhoods with high levels of income dispersion. Non-public Census data, specifically the 1990 and 2000 Census Long Form data, are used to identify, within census tracts, cohorts of households who moved in within the year prior to the Census, within 5 years prior to the Census and within 10 years prior to the Census. If recent in-migrants to mixed-income neighborhoods exhibit high levels of income heterogeneity, this is consistent with stable mixed-income neighborhoods. If, however, mixedincome neighborhoods are comprised of older homogenous lower-income (higher-income)

\footnotetext{
${ }^{1}$ This apparent contradiction between economic theory and empirical fact has led economic theorists to explore conditions under which equilibrium with mixed-income neighborhoods are possible (de Bartolome, 1990; Frankel, 1998; de Bartolome and Ross, 2003).
} 
cohorts combined with newer homogenous higher-income (lower-income) cohorts, this is consistent with transitioning neighborhoods.

An additional benefit of access to micro-level data with Census tract identifiers is that it is possible to investigate the demographic characteristics of the lower-income and higher-income residents of mixed-income neighborhoods. Previous researchers have raised the possibility that income-disperse neighborhoods could have far less heterogeneity in lifetime income dispersion (Fischer, 2003; Hardman and Ioannides, 2004; Krupka, 2008), but there has been little empirical exploration of this issue.

Our key findings are: (1) There is a sizeable, positive, but not perfect, correlation between the overall income dispersion of a neighborhood and the income dispersion of recent cohorts of migrants; (2) Neighborhoods with greater income dispersion attract a disproportionate fraction of both very low-income and very high-income migrants; (3) Because the correlations described in our first finding are considerably less than one, they indicate that neighborhood income dispersion does slowly erode over time; (4) There is moderate evidence that neighborhoods with greater income dispersion experience disproportionate changes in median income. (5) The demographic characteristics of migrants to mixed-income neighborhoods with respect to age and education suggest that neighborhoods with higher levels of income dispersion may be much less heterogeneous with respect to lifetime income. For example, many of the lowincome residents of more income-disperse neighborhoods are younger college-educated households who will likely experience fairly substantial income growth over time.

Both Krupka (2008) and Tach (2009) find that neighborhood income dispersion is positively, but not perfectly, correlated from one Census to the next. Ours, however, is the first study that can distinguish between the case of high mobility costs, in which older cohorts are 
slow to exit transitioning neighborhoods but newer in-migrants are a relatively homogenous

group, from the case in which more heterogeneous neighborhoods attract more heterogeneous inmigrants.

\section{Stable vs Transitioning Neighborhoods}

Tach (2009) reviews models of neighborhood change in the sociological literature (Park, 1942; Hoover and Vernon, 1959) and concludes, “A common theme across the neighborhood change literature is that mixed income neighborhoods are considered to be at a midpoint in a longer process of neighborhood change”(p.10). Likewise, Krupka (2008) reviews economic models of neighborhood sorting (Tiebout, 1956; Alonso, 1964; Schelling, 1969) and likewise concludes that mixed income neighborhoods are most likely observed in the transition between homogenous equilibrium neighborhoods.

Krupka (2008) analyzes data at the Census block group level linked between the 1980, 1990 and 2000 Decennial Censuses. Using the log standard deviation of income and the coefficient of variation of income as measures of neighborhood income dispersion, he finds that the level of neighborhood income dispersion observed in the cross-section is not stable over time. Neighborhoods with above average levels of income dispersion in one census experience large decreases in dispersion over the following decade. He does, however, find that the adjustment process is relatively slow, so that neighborhood dispersion measures are positively correlated from one Census to the next.

Tach (2009) analyzes Census tract-level data linked from 1970 to 2000 from the Neighborhood Change Database. She categorizes households as low, middle or high-income based on the $33^{\text {rd }}$ and $66^{\text {th }}$ percentile of household income in the metropolitan area. She then defines as mixed-income those neighborhoods that either (a) contain a relatively even fraction 
(25-40\%) of households from each of the three income groups, or (b) those that contain more than $75 \%$ high and low-income households, but less than $50 \%$ of either. She finds that only about half of these mixed-income neighborhoods remain categorized as mixed-income in the following Census.

Using fairly different empirical approaches, both Krupka (2008) and Tach (2009) find that much of the neighborhood income heterogeneity observed in a cross-section does not persist over time. At the same time, there is sufficient correlation in income heterogeneity across census years to suggest either that neighborhood transition is relatively slow, or that a subset of mixedincome neighborhoods are not in transition. This study further delves into the question of the stability of mixed-income neighborhoods by studying the income dispersion of recent cohorts of migrants to the neighborhood.

Figure 1 illustrates why comparisons of income dispersion by migration cohort are useful. Panel (a) of Figure 1 illustrates the income distribution of successive migrant cohorts into a neighborhood with a stable income distribution. The earlier and more recent cohorts of migrants have income distributions with similar medians and similar dispersion. Panel (b) of Figure 1 illustrates a potential pattern for a neighborhood going through income transition. In this case, the two cohorts of migrants exhibit similar income dispersion, both to each other and to the cohorts in panel (a), but median income shifts between the two cohorts. As a result, the overall income dispersion for the neighborhood in (b) is larger than that for the neighborhood in (a). If, however, we were to compare income dispersion by migrant cohort, we would find no difference in the income dispersion of the recent migrant cohort between neighborhoods (a) and (b), nor would we find any difference for the earlier migrant cohort. 
Figure 1, therefore, implies a useful set of comparisons. If the income dispersion of an individual migrant cohort is highly correlated with the overall income dispersion of the neighborhood population, this is consistent with stable neighborhood income distributions of the type illustrated in panel (a). If, however, there is little relationship between the income dispersion of an individual migrant cohort and the overall income dispersion of the neighborhood population, this indicates that neighborhoods with higher income dispersion are merely transitioning, rather than stable mixed-income neighborhoods.

Another obvious comparison suggested by Figure 1 is to compare changes in median income across successive cohorts. If mixed-income neighborhoods are predominantly transitioning neighborhoods, they should exhibit larger changes in median income across cohorts. We report our findings on these comparisons as well, but, for reasons discussed below, the cross-sectional Census data are less well suited to these sort of cross-cohort comparisons.

The simple illustration in Figure 1 also further clarifies why it is useful to study income dispersion by migrant cohort in addition to correlating neighborhood income dispersion measures across two points in time. In extreme cases, the two exercises would provide the same information. If mixed-income neighborhoods are perfectly stable, then income dispersion measures would be perfectly correlated over time and neighborhood income dispersion measures would be perfectly correlated with income dispersion of a given migrant cohort. If mixedincome neighborhoods were only briefly observed during a process of rapid neighborhood transition, then income dispersion measures would exhibit little correlation over time and neighborhood income dispersion measures would exhibit little correlation with the income dispersion of a migrant cohort. 
The more realistic case, supported by the findings of Krupka (2008) and Tach (2009), in which neighborhood income dispersion is positively, but far from perfectly, correlated over time, can occur for a variety of reasons. One possibility is that mobility costs are sufficiently high that older cohorts are slow to exit the transitioning neighborhood. In this case, the newer in-migrants are still a relatively homogenous group. Another possibility is that the more heterogeneous neighborhoods do attract a more heterogeneous group of migrants, but that the dispersion of the in-migrants is still less than the overall level of dispersion in the neighborhood. Our understanding of neighborhood sorting is advanced by distinguishing between the case in which more disperse neighborhoods do in fact attract more diverse migrants, compared to the case in which mobility costs are sufficiently high to slow transition.

\section{Data}

\section{A. Census Demographic Long Form Data}

The analysis in this paper uses the 1990 and 2000 Decennial Census Long Form Data. These are confidential data products of the U.S. Census Bureau that can only be accessed from a Census Research Data Center (CRDC). The Long Form Data contain the population of households that respond to the Long Form survey in the Decennial Census, which is administered to a 1-in-6 sample of all households in the U.S. The samples include 14.3 million households and 38.6 million individuals in the year 1990 and 16.6 million households and 43.5 million individuals in the year 2000.

The analysis in this paper would not be possible with publicly available data. The Public Use Microdata Samples (PUMS) contain a random sample of the Decennial Long Form surveys, but only identify Public Use Microdata Areas (PUMAs), which are areas of at least 100,000 people. In contrast, the confidential Long Form data identify census tracts, which contain an 
average of 4,000 individuals. ${ }^{2}$ The public Census data sets that report aggregate census tractlevel characteristics, which have been used in most of the other research on economic segregation, do not disaggregate by key variables such as the migration status of the household.

\section{B. Census Geography and Sample Criteria}

The U.S. Census Bureau attempts to maintain consistent census tract boundaries over time, but boundaries are sometimes changed as neighborhoods evolve and as tract populations increase or decrease. While much of our key analysis in conducted on separate cross-sections from the 1990 and 2000 Censuses, some of our analysis links tracts across the two census years. Census Tract Relationship Files from the U.S. Census Bureau show how 1990 census tracts relate to 2000 census tracts. This information can be used to develop a concordance file that aggregates tracts to create neighborhood definitions that are unique and consistent across the two census years. $^{3}$ If, for example, a 1990 tract split into two tracts in 2000, the two 2000 tracts can be merged into a single neighborhood that is consistent with the original 1990 tract. For less common cases of overlapping tract splits and merges, it is necessary to aggregate over several tracts to obtain one consistent neighborhood. ${ }^{4}$ In this paper, the terms neighborhood and census tract refer to these census tract groupings that are linked between 1990 and 2000.

We select our sample of census tracts for analysis from Consolidated Metropolitan Statistical Areas (CMSAs) as defined by the Census Bureau. We use the 72 CMSAs in the continental U.S. with populations of at least 500,000 in 1990. Because most CMSAs include

\footnotetext{
${ }^{2}$ The census block, an even smaller geographic unit, is also identified. Because, however, CRDC researchers are not currently allowed to link census data over time at the block level, and because the tract more closely relates to our concept of neighborhood, we conduct our analysis at the tract level. Using survey data, Lee and Campbell (1990) find that self reported neighborhoods of residence on average cover 15 square blocks. This finding suggests that census tracts offer a reasonable neighborhood definition for urban areas.

3 The methodology for linking tracts across the 2 censuses is described in more detail in McKinnish, Walsh and White (2010). We thank Randy Walsh for generously allowing us to use the tract-level linking that he developed in that paper.

${ }^{4} 82 \%$ of the constructed time-consistent neighborhoods contain only one 2000 census tract, and $94 \%$ contain no more than two 2000 census tracts.
} 
some areas that are very rural and in which census tracts cover very large geographic areas, we only select central city tracts, as defined by the Census Bureau. Our final sample consists of 12,338 linked tracts from 72 CMSAs. A list of included CMSAs appears in Appendix A.

\section{Measurement of Income and Income Variance}

The household income measure used in this paper sums all forms of income across all members of the householder's family. ${ }^{5}$ Income from unmarried partners is included in family income, but we exclude income from individuals in the household who are otherwise not related to the householder (such as roommates or boarders). An additional benefit of the micro-level data is that we have a large sample of household-level observations of income from which to calculate income dispersion measures. Because the aggregated data used in most other papers only reports counts for various intervals of household income, researchers have either had to create dispersion or segregation measures based on various income cut-offs (e.g. Massey and Eggers, 1990; Fischer, 2003; Tach, 2009) or interpolate household-level incomes based on these counts and assumptions about the distribution of income within each interval (e.g. Jargowsky, 1996).

The primary measure of tract-level income dispersion in this paper is the coefficient of variation $(\mathrm{CV})$ :

$$
C V=\frac{\sigma_{x}}{\bar{X}}
$$

5 The definition of family used by the Census Bureau is "two or more individuals related by birth, marriage, or adoption who reside together." Our income measure is similar to the family income measure used by the Census Bureau, the largest difference being that householders who do not reside with any relative are still included in our analysis. Unlike the definition of family income used by the Census Bureau, we include income from individuals designated as the unmarried partner of the householder. Individuals who do not live alone, but are not related to the householder, are not included in our analysis. Their income does not belong in the householder's family's income, but we do not have the migration information to create separate observations for them. 
but we also consider three other income dispersion measures: the ratio of the mean to the median (MM), the interquartile range standardized by the median (IQR), and the ratio of tract standard deviation to the metro-area standard deviation (R). ${ }^{6}$ Specifically:

$$
\begin{array}{r}
M M=\frac{\bar{X}}{X_{\text {med }}}, \\
I Q R=\frac{X_{75 p c t}-X_{25 p c t}}{X_{\text {med }}}, \\
R=\frac{\sigma_{X}}{\sigma_{X, C M S A}} .
\end{array}
$$

We wish our measures of dispersion to be pure measures of spread, uncorrelated with the median income of the tract. As in Krupka (2008), each measure of dispersion is therefore regressed separately on tract median income. The residuals from these regressions are therefore purged of correlation with tract median income. These residuals are used in all analyses in this paper.

Table 1 reports the correlations among our four income dispersion measures (in residual form). While these measures are all positively correlated, the correlations range from 0.304 to 0.795, so the different measures do capture different information about the income distribution within the tract. If we were to report results from all of our specifications in the paper using all four dispersion measures, the number of tables would be quite prohibitive. As a result, we report results using the coefficient of variation for all of our specifications, as it is one of the most

\footnotetext{
${ }^{6}$ Our use of the ratio of the neighborhood standard deviation to the metro-area standard deviation is motivated by the use of the ratio of the between neighborhood variance to the metro-area variance as a measure of segregation at the metropolitan level in the economic segregation literature (Jargowsky,1996; Farley, 1977). Jargowsky (1996) uses the ratio of the between-neighborhood standard deviation in income and the overall metro-area standard deviation to measure economic segregation at the metropolitan level, arguing that this adjusts for changes in the underlying income distribution.
} 
commonly used measures of dispersion, report results using other dispersion measures for our key specification described below in equation (1), and report additional results using the other dispersion measures in the appendix.

Table 2 regresses tract-level CV on tract demographic characteristics to provide descriptive characteristics of the neighborhoods with higher income dispersion. These regressions also control for MSA fixed-effects. In 1990, the tracts with higher income dispersion had larger black populations, a larger fraction college graduates, more very young householders as well as more very old householders, and lower median income. ${ }^{7}$ The results for 2000 are similar, but the coefficients on \% college-educated and median income are small and insignificant.

The final column adds variables that measure the amount of positive change in median income between 1990 and 2000 and the amount of negative change in median income between 1990 and 2000. Specifically, one variable is the absolute change in median income between 1990 and 2000 interacted with an indicator for positive change, and the other variable is the same measure of absolute change interacted with an indicator for negative change. These results indicate that larger values of CV are associated with both larger increases and larger decreases in median income, which is consistent with the idea that at least part of the dispersion is due to neighborhood transition. Both Ellen and O'Regan (2008) and McKinnish, Walsh and White (2010) find that there was substantial income growth or gentrification in many previously lowincome neighborhoods during the 1990's. It is therefore possible that neighborhood transition was sufficiently prevalent during this period to generate many of the economically heterogeneous neighborhoods.

\footnotetext{
${ }^{7}$ While the correlation between CV and median income was purged in the simple regression, these two variables can still be correlated once other controls are added to the model.
} 


\section{Migration Cohorts}

The PUMS data report, for each household member, whether or not he or she lived in the same housing unit 5 years prior to the survey. The confidential data, fortunately, provide even more detailed information on when the householder moved into his or her current residence. For example, in the 2000 data, householders report whether they moved into their current residence from 1999 to 2000, from 1995 to 1998, from 1990 to 1994, or prior. Analogous information is obtained in the 1990 Census. These responses are used to create three cohorts of migrants: those current residents who moved in roughly 5 to 10 years ago (Mig10), those who moved in roughly 5 to 1 years ago (Mig5), and those who moved in roughly during the past year (Mig1). ${ }^{8}$

Each of the above income dispersion measures is calculated on each of these three subsamples of migrants, in addition to the full sample of households within each tract. Comparing the income dispersion measures between the migrant groups and the full sample allows us to make the sort of comparisons suggested by Figure 1. Specifically, we can ascertain how the income dispersion for any given migrant group compares between tracts with high overall income dispersion measures and those with low overall income dispersion. If there is a high degree of correlation between overall income dispersion and income dispersion within migrant group, this is more consistent with stable income-disperse neighborhoods, as shown in panel (a) of Figure 1. A lower degree of correlation is more consistent with transitioning neighborhoods, as show in panel (b) of Figure 1.

One limitation of this research approach is that we do not observe a random sample of households in each migration cohort. We only observe a random sample of, for example, those households that migrated in between 1990 and 1994 and remained through the 2000 Census.

\footnotetext{
${ }^{8}$ The Decennial Census records residency for April 1 of the Census year. Mig1 therefore contains, for eample, those householders who moved in during 1999 or the first few months of 2000.
} 
To the extent that there is non-random exit from the cohort, this will tend to reduce the income dispersion measures for the cohorts. For example, in Figure 1, as neighborhood B transitions to higher income, it is possible that a disproportionate number of the households in the lower tail of the earlier cohorts will exit. This will act to further decrease the correlation between the overall income dispersion and the income dispersion within any cohort of migrants. An additional limitation is that we do not observe household income at the time that they move into their current residence, only their incomes at the time of the Census.

The most recent cohort of migrants is therefore of particular interest. For those households who moved into their current residence within the past year, the neighborhood characteristics in the Census closely approximate the neighborhood characteristics when they chose that location. The incomes of these households reported in the Census should closely match their incomes at the time of their move. Additionally, because of the recent nature of their arrival, there are fewer exits from this cohort by the time of the Census. As a result, the sample of households in this cohort in the Census most closely approximates the full set of in-migrants who moved in during that time period, compared to the other two migration cohorts. If the income dispersion in this group of recent migrants is quite a bit larger in neighborhoods with higher overall income dispersion, this suggests that high dispersion neighborhoods are not merely the result of transitioning neighborhoods with slow exit.

The data issues raised above limit our ability to successfully make comparisons of median income across successive cohorts of migrants. For the analysis using income dispersion measures, these data issues can be circumvented to a certain extent by focusing on the most recent cohort of in-migrants. The median income of the most recent cohort, however, is only informative when compared to the median income of earlier cohorts of in-migrants. Because 
these earlier cohorts have experienced non-random exit and changes in income since they first arrived in the neighborhood, there is no way to perform the analysis of shifts in median income that is not subject to these considerable limitations.

One additional unfortunate gap in information in the Decennial Census is that there is no way to identify whether migrant householders previously lived in another housing unit in the same neighborhood or whether they moved in from another census tract. The only information available is whether or not the householder lived in the same county five years prior to the Census. ${ }^{9}$ To the extent that those households who have relocated within the same tract have already incurred the migration cost associated with changing residences, they can still be thought of as having chosen their current tract among a set of neighboring census tracts within the same metropolitan area.

\section{Methods}

\section{A. Comparing income dispersion measures by migrant cohort}

The following regression model estimates how the income dispersion for a given migrant cohort compares across tracts with different levels of overall income dispersion:

$$
\begin{aligned}
C V_{c t m} & =\beta_{0}+\beta_{1}\left(F C V_{t} * M i g 10_{c}\right)+\beta_{2}\left(F C V_{t} * \operatorname{Mig}_{c}\right)+\beta_{3}\left(F C V_{t} * M i g 1_{c}\right) \\
& +\beta_{4} \operatorname{Mig}_{c}+\beta_{5} \operatorname{Mig}_{c}+\beta_{6} \operatorname{MedInC}_{t}+C M S A_{m} \delta+\varepsilon_{c t m}
\end{aligned}
$$

where $C V_{c t m}$ is the coefficient of variation for migrant cohort $c$ in tract $t$ in CMSA $m$. Mig10, Mig5 and Mig1 are indicator variables for the three cohorts of migrants: Mig10 equals one for the sample of households who arrived 5 to 10 years ago; Mig5 equals one for the sample of households who arrived 5 to 1 years ago; and Mig1 equals one for the sample of households who arrived in the past year. FCV is coefficient of variation for the full sample of households in the

\footnotetext{
${ }^{9}$ The PUMS data provide more refined geographical detail on previous location by identifying PUMA of residents five years prior. This information is not available in the non-public long form files.
} 
tract. MedInc is the median income of the tract and the vector $C M S A_{m}$ controls for CMSA fixedeffects. Equation (1) is re-estimated using our three other income dispersion measures: MM, R and IQR. In each case, the dependent variable and the full-sample measures are each replaced accordingly.

The coefficients $\beta_{1}, \beta_{2}$ and $\beta_{3}$ map directly into the comparisons by migrant cohort indicated by the discussion of Figure 1. We wish to compare, for a given migrant cohort, how the income dispersion for that particular cohort varies between high dispersion tracts and low dispersion tracts. In equation (1), if $\beta_{1}$ is positive, this indicates that tracts with higher income variance in the full sample also have higher income variance in the cohort of households who moved in 5 to 10 years ago. Similar interpretations are given to $\beta_{2}$ and $\beta_{3}$. If mixed-income neighborhoods are merely in transition, as described in Figure 1, these coefficients should be close to zero. Coefficients that suggest a high degree of correlation between the income variances of the full sample and the migrant cohorts are consistent with stable mixed-income neighborhoods. For the reasons discussed above, $\beta_{3}$ is of particular interest, as it reflects the income dispersion for those households who have moved in during the past year.

One concern about the specification in equation (1) could be that the households used to calculate the dependent variable, the income dispersion measures for each migration cohort, are also used to compute an independent variable, the full sample income dispersion measure, therefore inducing a correlation between the two measures. As shown in Figure 1, the full sample measure can still be quite uncorrelated from the migration cohort measures if higher overall income dispersion only occurs in transitioning neighborhoods. In order to more fully address this concern, we also estimate a version of equation (1) using the 2000 Census data, in which we substitute in the full-sample income dispersion measure obtained using the 1990 
Census data. This alternative specification therefore estimates the relationship between the tract's income dispersion in 1990 and the income dispersion in 2000 of those cohorts who had moved in between 1990 and 1995, between 1995 and 1999 and between 1999 and April 2000. A strong relationship between the 1990 income dispersion and the income dispersion for the cohorts arriving in 1999 and early 2000 would indeed be sizeable evidence of stable mixedincome neighborhoods.

\section{B. Comparing income distributions by migrant cohort}

Equation (1) compares summary measures of income dispersion across neighborhoods. It would be even more satisfying to directly compare the full income distributions themselves, similar to what is done in Figure 1. It is easy to compare a single high dispersion neighborhood to a single low dispersion neighborhood, replicating the graphical analysis in Fig 1, by creating histograms or density estimates for each migrant cohort for each of the two neighborhoods. One

could directly compare the income distributions and see how, for each migrant cohort, they differ between the two different neighborhoods. Something very analogous to this exercise can be accomplished by first dividing the households into several income groups. The following categories of household income are based on the metropolitan area's median household income:

I1: Income less than $50 \%$ of the metro-area median

I2: Income $50-100 \%$ of the metro-area median

I3: Income $100-150 \%$ of the metro-area median

I4: Income $150-200 \%$ of the metro-area median

I5: Income greater than $200 \%$ of the metro-area median 
Table 3 provides a descriptive breakdown of these categories. For example, in 1990, the average tract in our sample had 33.1\% of households in the lowest income category and $12.3 \%$ of households in the highest income category.

These income distribution statistics for households in each tract are used in the following regression specification:

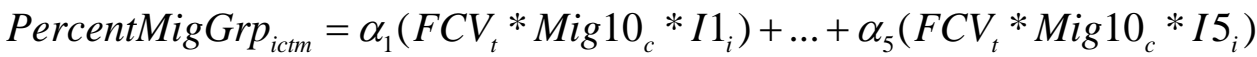

$$
\begin{aligned}
& +\beta_{1}\left(F C V_{t} * \operatorname{Mig}_{c} * I 1_{i}\right)+\ldots+\beta_{5}\left(F C V_{t} * \operatorname{Mig5}_{c} * I 5_{i}\right) \\
& +\gamma_{1}\left(F C V_{t} * \operatorname{Mig}_{c} * I 1_{i}\right)+\ldots+\gamma_{5}\left(F C V_{t} * M i g 1_{c} * I 5_{i}\right)
\end{aligned}
$$

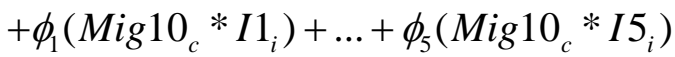

$$
\begin{aligned}
& +\phi_{6}\left(\operatorname{Mig}_{c} * I 1_{i}\right)+\ldots+\phi_{10}\left(\operatorname{Mig}_{c} * I 5_{i}\right) \\
& +\phi_{11}\left(\operatorname{Mig}_{c} * I 1_{i}\right)+\ldots+\phi_{15}\left(\operatorname{Mig} 1_{c} * I 5_{i}\right) \\
& +\phi_{16} \text { MedInc }_{t}+C M S A_{m} \delta+\varepsilon_{i c t m}
\end{aligned}
$$

Where PercentMigGrp is the percent of migrant cohort $c$ in tract $t$ that is in income category $i$ in CMSA $m$. In other words, PercentMigGrp sums to one across the 5 income categories for each migrant group in each tract. I1-I5 are indicator variables for the 5 income categories.

The parameters $\alpha_{1}-\alpha_{5}$ effectively trace out the relative income distribution of Mig10 cohort households in high dispersion neighborhoods compared to low dispersion neighborhoods. If, for example, $\alpha_{1}>0$, this indicates that higher dispersion neighborhoods receive disproportionately more of the Mig10 households in the lowest income category compared to the lower dispersion neighborhoods. If, for example, both $\alpha_{1}$ and $\alpha_{5}$ are positive, this indicates that the income distribution of Mig10 households has thicker tails in higher dispersion neighborhoods than lower dispersion neighborhoods. Once again, $\gamma_{1}-\gamma_{5}$, the estimates for those households who moved into the neighborhood in the past year, are of particular interest. 
As was the case with equation (1), we estimate a separate version of equation (2) using 2000 Census data in which we substitute in the tract's full sample income dispersion measure obtained from the 1990 Census.

\section{Results}

\section{A. Income Dispersion by Migration Cohort}

Table 4 reports estimates from the regression specification in equation (1) using all four income dispersion measures. The top panel reports results using the 1990 Census. The main finding is that there is a fairly strong positive relationship between the full sample income dispersion measure and the income dispersion of the individual migration cohorts. The smallest estimates are obtained using the coefficient of variation, with coefficients ranging from 0.465 to 0.589. The coefficients obtained using the ratio of mean to median and the interquartile range are quite large in magnitude, in the range of 0.8 to 1.0. Another finding from these results is that there is a fair amount of stability in coefficient estimates across the three migration cohorts, and that the coefficients on the most recent year of in-migrants are relatively large in magnitude.

The results in the next panel using the 2000 census are very similar. While the coefficients on the older cohorts of migrants tend to be slightly lower in magnitude than those obtained in the 1990 Census, the coefficients on the most recent cohort of migrants are somewhat larger in magnitude.

The bottom panel of Table 4 uses the 2000 Census measure of income dispersion for each migrant cohort, but uses the 1990 Census measure of the full-sample income dispersion. Therefore, the samples that are used to compute the income dispersion measures for the migrant cohorts are not used to calculate the full-sample income dispersion. Not surprisingly, the coefficient estimates obtained from this regression are smaller in magnitude than those in the 
previous panels. The estimates still indicate a positive relationship between the 1990 tract-level income dispersion and the income dispersion of the cohort of migrants that arrive between 1999 and April 2000. The coefficient estimates range from a modest 0.270 to a quite sizeable 0.668 .

\section{B. Income Distribution by Migration Cohort.}

Table 4 reports estimates from equation (2). Because of the number of parameter estimates in this specification, we only report the results using the coefficient of variation. Estimates using the other income dispersion measures are reported in the Appendix B. In all three columns of Table 5, and for all three migration cohorts, the estimates show that the more income disperse neighborhoods have a disproportionately higher fraction of households in the lowest and highest income category, and a correspondingly lower fraction of households in the middle three income categories. The results are just as strong in column 3, when the tract's full sample CV calculated using the 1990 Census is substituted into the analysis for the 2000 Census data. In contrast to the Table 3 results that indicate that income dispersion erodes over time, these results suggest that mixed-income neighborhoods persist in their ability to attract new residents from the tails of the income distribution.

Strikingly similar results, reported in Appendix Table B1, are obtained using the other three measures of income dispersion.

\section{Income Dispersion and Neighborhood Transition}

Returning to Figure 1, another feature of interest for income-disperse neighborhoods is whether they, as depicted in panel (b), are experiencing relatively larger shifts in median income across the migrant cohorts. The results in the $3^{\text {rd }}$ column of Table 2 suggest this may be the case, as they indicate that those tracts with greatest income dispersion in 2000 experienced greater income change, in either a positive or negative direction, between 1990 and 2000. 
As discussed above, the analysis of median income shifts across cohorts is more tentative due to the limitations of our cross-sectional data. Nevertheless, equation (1) can be appropriately modified to investigate this outcome by first replacing the dependent variable with median household income of migrant cohort $\mathrm{c}$ in tract $\mathrm{t}$ :

$$
\begin{aligned}
\log \left(\operatorname{MedInc}_{c t m}\right)= & \beta_{0}+\beta_{1}\left(F C V_{t} * \operatorname{Mig10}_{c} * \operatorname{Pos}_{t}\right)+\beta_{2}\left(F C V_{t} * \operatorname{Mig10}_{c} * \operatorname{Neg}_{t}\right) \\
& +\beta_{3}\left(F C V_{t} * \operatorname{Mig}_{c} * \operatorname{Pos}_{t}\right)+\beta_{4}\left(F C V_{t} * \operatorname{Mig}_{c} * \operatorname{Neg}_{t}\right) \\
& +\beta_{5}\left(F C V_{t} * \operatorname{Mig}_{c} * \operatorname{Pos}_{t}\right)+\beta_{6}\left(F C V_{t} * \operatorname{Mig}_{c} * N e g_{t}\right) \\
& +\beta_{7} \operatorname{Mig}_{c}+\beta_{8} \operatorname{Mig}_{c}+\beta_{9} \operatorname{MedInc}_{t}+\operatorname{CMSA}_{m} \delta+\varepsilon_{i c t m}
\end{aligned}
$$

On the right hand side, the key independent variables from equation (1) are interacted with two indicator variables. Pos is an indicator variable that equals one if the change in median income from the Mig10 cohort to the Mig1 cohort is above the median change in the sample of tracts. $\mathrm{Neg}$ is an indicator variable that equals one if the change in median income from the Mig10 cohort to the Mig1 cohort is below the median change in the sample of tracts. In other words, Pos and Neg sort the tracts into those that are experiencing above median and below median income growth across these cohorts. ${ }^{10}$

If more income disperse neighborhoods experience greater shifts in income, then we expect to obtain positive coefficient estimates for $\beta_{3}$ and $\beta_{5}$, and negative coefficient estimates for $\beta_{4}$ and $\beta_{6}$. Much like the coefficients in column 3 of Table 2, these results would indicate that more disperse neighborhoods are experiencing greater shifts in median income, whether in a positive or negative direction. If the transition is consistently in the same direction across the cohorts, we would expect the $\beta_{5}$ and $\beta_{6}$ coefficient estimates to be larger in magnitude than the $\beta_{3}$ and $\beta_{4}$ coefficients.

\footnotetext{
${ }^{10}$ Because more recent cohorts of in-migrants are younger and more mobile, it is not appropriate to simply sort tracts into those who have positive and negative changes in median income across the cohorts.
} 
The predictions are less clear for the estimates of $\beta_{1}$ and $\beta_{2}$. Holding constant tract-

level median income in the current census, a tract that experienced larger income growth across the cohorts likely started at a lower initial level of income, suggesting that $\beta_{1}$ is likely to be more negative than $\beta_{2}$. Likewise, tracts that are experiencing larger income declines should be starting at relatively higher incomes in earlier cohorts.

Estimates from equation (3) are reported in Table 6. The results regarding shifts in median income across migrant cohorts are mostly, but not entirely, consistent with expectations. The coefficients on the positive trend interactions do suggest that the more income disperse neighborhoods in this group of tracts are starting out as initially lower income neighborhoods, but experiencing relatively larger income growth across the migrant cohorts. For the coefficients on the negative trend interactions, the 1990 coefficients indicate that the more income disperse neighborhoods in this group of tracts are experiencing relatively larger income declines across the migrant cohorts. The 2000 coefficients on the negative trend interactions, while negative, do not indicate large declines across cohorts for the more income disperse neighborhoods. ${ }^{11}$

\section{Demographic Characteristics of In-Migrants to Income Disperse Neighborhoods}

While equations (1)-(3) analyze tract-level characteristics, the individuallevel data can be used to examine the demographic characteristics of in-migrants to the more income disperse neighborhoods compared to in-migrants to the less income disperse neighborhoods. Households are categorized into three income groups, which are created by collapsing the five income categories used in Table 5:

\footnotetext{
${ }^{11}$ Results obtained using the other three income dispersion measures are reported in Appendix Table B2. Results obtained using the MM measure are entirely consistent with neighborhood income transitions. Results using the R measure are mixed: the coefficients for the negative trend interactions are consistent with income transitions, the coefficients on the positive trend interactions are not. Results using the IQR measure are not consistent with neighborhood income transitions.
} 
Low-Income: Income class I1,

Middle-Income: Income class I2-I4,

High Income: Income class I5.

Householders are also categorized into three age groups:

Young: Householder <30 Years old,

Prime: Householder 30-60 Years old,

Older: Householder>60 Years old.

Nine demographic categories are created based on these three income groupings and three age groupings. Equation (4) estimates which of these demographic groups disproportionately send migrants to tracts with greater income variance:

(4) $C V_{i t m}=\sum_{j=1}^{3} \sum_{k=1}^{3} \beta_{j, k}\left(\right.$ IncomeGroup $_{i j} *$ Age $\left._{i k}\right)+X_{i t} \gamma_{1}+$ Medinc $_{t} \gamma_{2}+C M S A_{m} \gamma_{3}+\varepsilon_{i t m}$

In equation (4), the age*income groups from which migrants have the greatest propensity to locate in high dispersion neighborhoods will have the more positive estimates for $\beta$. When estimating equation (4), an intercept term is added and one of the nine groups is dropped, so that the results in Table 7 are all relative to that omitted reference group. Equation (4) also includes controls for race/ethnicity (white non-Hispanic, black non-Hispanic, and Hispanic), education (less than high school degree, high school degree, college), presence of children, tract median income and CMSA fixed-effects.

For additional analysis, householders are further categorized into three education groups: $<$ HS: Less than High School, HS: High School or Some College, College: College Degree or More. 
These education categories are used in combination with the income and age groups to create 27 demographic categories. Equation (5) modifies equation (4) to include this more refined categorization:

(5) $C V_{i t m}=\sum_{j=1}^{3} \sum_{k=1}^{3} \sum_{l=1}^{3} \beta_{j, k, l}\left(\right.$ IncomeGroup $_{i j} *$ Age $\left._{i k} * E_{\text {duc }}\right)+X_{i l} \gamma_{1}+$ Medinc $_{t} \gamma_{2}+C M S A_{m} \gamma_{3}+\varepsilon_{i t m}$

As was the case for equation (4), larger positive values of $\beta$ indicate those demographic groups from which migrants disproportionately locate in high dispersion neighborhoods. As was also the case for equation (4), for estimation an intercept term is added to equation (5) and one demographic group dropped as an omitted reference group.

Both equations (4) and (5) are estimated on the sample of all householders who moved into their current residence in the past 10 years (those in the Mig10, Mig 5 and Mig1 cohorts). These two equations are also estimated on the sub-sample of households who moved in the past year (those in the Mig1 cohort).

Table 7 reports coefficient estimates from equation (4) for both the full sample of migrants and the subsample of recent migrants. These results are consistent with those from Table 5, indicating that the income disperse neighborhoods disproportionately attract migrants from the lowest and highest income categories. Within the lower income category, it is the youngest householders that disproportionately locate in income disperse neighborhoods. Within the highest income bracket, all of the age categories are relatively more likely to locate in high dispersion neighborhoods, but the relationship is particularly strong for the oldest group of householders. It is particularly interesting that this result for older households is just as strong for the sample of very recent in-migrants. Therefore, the presence of older households in mixedincome neighborhoods is not just a lifecycle effect, in which long-time residents have aged and are starting to be replaced by younger, lower-income households. 
Table 8 reports coefficient estimates from equation (5). The same patterns with regard to age and income class that appeared in Table 7 are also evident here. Additionally, within each age and income class, the migrant householders with a college degree are much more likely than average to locate in more disperse neighborhoods.

Taken as a whole, the findings in Tables 7 and 8 suggest that neighborhoods with greater dispersion in annual income may not be nearly as disperse in lifetime income. College-educated households experience greater changes in income over their lifecycle compared to less-educated workers. For example, young college-educated households may locate in neighborhoods with a higher median income because their expected average annual income across their lifetime is much larger than their current annual income would suggest.

\section{Conclusions}

Our results suggest that neighborhoods with greater income dispersion do in fact attract a more economically diverse set of in-migrants, particularly disproportionately more migrants from the tails of the income distribution. At the same time, these results also indicate that high levels of income dispersion do not persist over time, and that the new arrivals to mixed-income neighborhoods are less heterogeneous than the neighborhood as a whole. Taken together, our findings suggest that the level of economic integration observed in a single cross-section is the result of a combination of neighborhood transition and the fact that neighborhoods do vary in the heterogeneity of residents they attract.

Not surprisingly, the analysis in this paper suggests that neighborhood sorting and neighborhood evolution is a complex process that does not easily conform to a simple theoretical model. While it is true that the income dispersion in mixed-income neighborhoods does appear to erode over time, the empirical results are not consistent with a simple model of slow 
neighborhood transition due to mobility costs. The income dispersion is not just a product of a failure of older cohorts to exit, but in fact, also results from the inflow of an economically diverse group of in-migrants.

Additionally, our results also suggest that the residents of mixed-income neighborhoods may be less heterogeneous with respect to lifetime income. This has important implications in that it suggests that households with permanently low incomes are less likely to inhabit mixedincome neighborhoods than households with temporarily low incomes. Therefore, to the extent that mixed-income neighborhoods buffer the effects of individual-level income inequality, households with chronically low incomes are less likely to receive these benefits. 


\section{References}

Alonso, William. 1964. Location and Land Use. Cambridge, MA: Harvard University Press.

de Bartholome, Charles. 1990. "Equilibrium and inefficiency in a community model with peer group effects.” Journal of Political Economy 98(1): 110-133.

De Bartolome, Charles and Stephen Ross. 2003. "Equilibria with local governments and commuting: income sorting vs income mixing.” Journal of Urban Economics 54(1):1-20

Ellen, Ingrid and Katherine O’Regan. 2008. "Reversal of Fortunes? Lower-income Urban Neighbourhoods in the US in the 1990s,” Urban Studies 45 (4): 845-869.

Farley, Reynolds. 1977. "Residential segregation in urbanized areas of the United States in 1970: an analysis of social class and racial differences.” Demography 14:497-517.

Frankel, D. 1998. “A pecuniary reason for income mixing.” Journal of Urban Economics. 44: 158-69.

Fischer, Mary. 2003. “The relative importance of income and race in determining residential outcomes in U.S. urban areas, 1970-2000.” Urban Affairs Review 38(5): 669-96.

Hardman, Anna and Yannis Ioannides. 2004. "Neighbors' income distribution: economic segregation and mixing in US urban neighborhoods.” Journal of Housing Economics 13( ): 368-82.

Hoover, Edgar and Raymond Vernon. 1959. Anatomy of a metropolis: The changing distribution of people and jobs within the New York metropolitan area. Cambridge: Harvard University Press.

Jargowsky, Paul. 1996. "Take the money and run: economic segregation in U.S. metropolitan areas” American Sociological Review 61( ) 984-98.

Jargowsky, Paul and Rebecca Yang. 2006. “The 'underclass' revisited: a social problem in decline.” Journal of Urban Affairs 28(1): 55-70.

Krupka, Douglas. 2008. “The stability of mixed income neighborhoods in America.” IZA Discussion Paper No. 3370.

Lee, B. and K. Campbell. 1990. "Common Ground? Urban Neighborhoods as Survey Respondents See Them,” Unpublished Manuscript.

Massey, Douglas and Mitchell Eggers. 1990. "The ecology of inequality: minorities and the concentration of poverty, 1970-1980.” American Journal of Sociology 95(5) 1153-88.

Massey, Douglas and Mary Fischer. 2003. “The geography of inequality in the United States, 
1950-2000.” Brookings-Wharton Papers on Urban Affairs 1-40

Mayer, Susan. 2001. "How the growth in income inequality increased economic segregation" Harris School Working Paper \#01-17.

McKinnish, Terra, Randall Walsh and T. Kirk White. 2010. "Who gentrifies low-income neighborhoods?” Journal of Urban Economics 67(2): 180-93.

Park, Robert. 1952. Human Communities Glencoe, IL: Free Press.

Schelling. Thomas. 1969. "Models of segregation” American Economic Review 59(2): 488493.

Tach, Laura. 2009. “The stability of mixed-income neighborhoods.” Unpublished manuscript.

Tiebout, Charles. 1956. “A pure theory of local expenditures.” Journal of Political Economy 64:416-424. 
Appendix A. MSA/CMSAs list

\begin{tabular}{|l|l|}
\hline Code & MSA/CMSA Name \\
\hline 0160 & Albany-Schenectady-Troy, NY \\
\hline 0200 & Albuquerque, NM \\
\hline 0240 & Allentown-Bethlehem-Easton, PA \\
\hline 0520 & Atlanta, GA \\
\hline 0640 & Austin-San Marcos, TX \\
\hline 0680 & Bakersfield, CA \\
\hline 0760 & Baton Rouge, LA \\
\hline 1000 & Birmingham, AL \\
\hline 1122 & Boston-Worcester-Lawrence, MA--NH--ME--CT \\
\hline 1280 & Buffalo-Niagara Falls, NY \\
\hline 1440 & Charleston-North Charleston, SC \\
\hline 1520 & Charlotte-Gastonia-Rock Hill, NC-SC \\
\hline 1602 & Chicago-Gary-Kenosha, IL-IN-WI \\
\hline 1642 & Cincinnati-Hamilton, OH-KY-IN \\
\hline 1692 & Cleveland-Akron, OH \\
\hline 1840 & Columbus, OH \\
\hline 1922 & Dallas-Fort Worth, TX \\
\hline 2000 & Dayton-Springfield, OH \\
\hline 2082 & Denver-Boulder-Greeley, CO \\
\hline 2162 & Detroit-Ann Arbor-Flint, MI \\
\hline 2320 & El Paso, TX \\
\hline 2840 & Fresno, CA \\
\hline 3000 & Grand Rapids-Muskegon-Holland, MI \\
\hline 3120 & Greensboro--Winston-Salem--High Point, NC \\
\hline 3160 & Greenville-Spartanburg-Anderson, SC \\
\hline 3240 & Harrisburg-Lebanon-Carlisle, PA \\
\hline 3280 & Hartford, CN \\
\hline 3362 & Houston-Galveston-Brazoria, TX \\
\hline 3480 & Indianapolis, IN \\
\hline 3600 & Jacksonville, FL \\
\hline 3760 & Kansas City, MO \\
\hline 3840 & Knoxville, TN \\
\hline 4120 & Las Vegas, NV \\
\hline
\end{tabular}




\begin{tabular}{|l|l|}
\hline 4400 & Little Rock-North Little Rock, AR \\
\hline 4472 & Los Angeles-Riverside-Orange County, CA \\
\hline 4520 & Louisville, KY-IN \\
\hline 4920 & Memphis, TN-AR-MS \\
\hline 4992 & Miami-Ft. Lauderdale, FL \\
\hline 5082 & Milwaukee-Racine, WI \\
\hline 5120 & Minneapolis-St. Paul, MN-WI \\
\hline 5360 & Nashville, TN \\
\hline 5560 & New Orleans, LA \\
\hline 5602 & New York-Northern New Jersey-Long Island, NY--NJ--CT--PA \\
\hline 5720 & Norfolk--Virginia Beach--Newport News, VA--NC \\
\hline 5880 & Oklahoma City, OK \\
\hline 5920 & Omaha, NE--IA \\
\hline 5960 & Orlando, FL \\
\hline 6162 & Philadelphia--Wilmington--Atlantic City, PA--NJ--DE--MD \\
\hline 6200 & Phoenix--Mesa, AZ \\
\hline 6280 & Pittsburgh, PA \\
\hline 6442 & Portland--Salem, OR--WA \\
\hline 6480 & Providence--Fall River--Warwick, RI--MA \\
\hline 6640 & Raleigh--Durham--Chapel Hill, NC \\
\hline 6760 & Richmond--Petersburg, VA \\
\hline 6840 & Rochester, NY \\
\hline 6922 & Sacramento--Yolo, CA \\
\hline 7040 & St. Louis, MO--IL \\
\hline 7160 & Salt Lake City--Ogden, UT \\
\hline 7240 & San Antonio, TX \\
\hline 7320 & San Diego, CA \\
\hline 7362 & San Francisco--Oakland--San Jose, CA \\
\hline 7560 & Scranton-Wilkes-Barre-Hazelton, PA \\
\hline 7602 & Seattle--Tacoma--Bremerton, WA \\
\hline 8000 & Springfield, MA \\
\hline 8160 & Syracuse, NY \\
\hline 8280 & Tampa--St. Petersburg--Clearwater, FL \\
\hline 8400 & Toledo, OH \\
\hline & Tucson, AZ \\
\hline
\end{tabular}




\begin{tabular}{|l|l|}
\hline 8560 & Tulsa, OK \\
\hline 8872 & Washington--Baltimore, DC--MD--VA--WV \\
\hline 8960 & West Palm Beach--Boca Raton, FL \\
\hline 9320 & Youngstown--Warren,OH \\
\hline
\end{tabular}


Appendix Table B1 Table 5 extension with additional income dispersion measures

\begin{tabular}{|c|c|c|c|c|c|c|}
\hline & \multicolumn{3}{|c|}{$\mathrm{R}$} & \multicolumn{3}{|c|}{ MM } \\
\hline & 1990 Census & 2000 Census & 2000 Census * & 1990 Census & 2000 Census & 2000 Census * \\
\hline Full Sample CV* Mig10*I1 & $0.028(0.004)$ & $0.034(0.003)$ & $0.010(0.003)$ & $0.204(0.005)$ & $0.169(0.004)$ & $0.133(0.005)$ \\
\hline Full Sample CV* Mig10*I2 & $-0.030(0.003)$ & $-0.038(0.003)$ & $-0.033(0.003)$ & $-0.137(0.005)$ & $-0.133(0.004)$ & $-0.139(0.005)$ \\
\hline Full Sample CV* Mig10*I3 & $-0.049(0.003)$ & $-0.048(0.003)$ & $-0.038(0.003)$ & $-0.163(0.005)$ & $-0.120(0.004)$ & $-0.119(0.005)$ \\
\hline Full Sample CV* Mig10*I5 & $0.079(0.003)$ & $0.082(0.003)$ & $0.081(0.003)$ & $0.171(0.005)$ & $0.144(0.004)$ & $0.176(0.005)$ \\
\hline Full Sample CV* Mig5*I1 & $0.043(0.003)$ & $0.040(0.003)$ & $0.011(0.003)$ & $0.215(0.005)$ & $0.163(0.004)$ & $0.110(0.005)$ \\
\hline Full Sample CV* Mig5*I2 & $-0.030(0.003)$ & $-0.040(0.003)$ & $-0.031(0.003)$ & $-0.168(0.005)$ & $-0.144(0.004)$ & $-0.150(0.005)$ \\
\hline Full Sample CV* Mig5*I3 & $-0.049(0.003)$ & $-0.047(0.003)$ & $-0.033(0.003)$ & $-0.156(0.005)$ & $-0.115(0.004)$ & $-0.102(0.005)$ \\
\hline Full Sample CV* Mig5*I4 & $-0.026(0.003)$ & $-0.022(0.003)$ & $-0.014(0.003)$ & $-0.060(0.005)$ & $-0.039(0.004)$ & $-0.027(0.005)$ \\
\hline Full Sample CV* Mig5*I5 & $0.062(0.003)$ & $0.069(0.003)$ & $0.066(0.003)$ & $0.169(0.005)$ & $0.135(0.004)$ & $0.169(0.005)$ \\
\hline Full Sample CV* Mig1*I1 & $0.053(0.003)$ & $0.054(0.003)$ & $0.030(0.003)$ & $0.183(0.005)$ & $0.147(0.004)$ & $0.097(0.005)$ \\
\hline Full Sample CV* Mig1*I2 & $-0.030(0.003)$ & $-0.043(0.003)$ & $-0.033(0.003)$ & $-0.163(0.005)$ & $-0.154(0.004)$ & $-0.154(0.005)$ \\
\hline Full Sample CV* Mig1*I3 & $-0.042(0.003)$ & $-0.042(0.003)$ & $-0.030(0.003)$ & $-0.114(0.005)$ & $-0.084(0.004)$ & $-0.072(0.005)$ \\
\hline Full Sample CV* Mig1*I4 & $-0.021(0.003)$ & $-0.018(0.003)$ & $-0.012(0.003)$ & $-0.032(0.005)$ & $-0.022(0.004)$ & $-0.009(0.005)$ \\
\hline Full Sample CV* Mig1*I5 & $0.040(0.003)$ & $0.049(0.003)$ & $0.045(0.003)$ & $0.125(0.005)$ & $0.113(0.004)$ & $0.138(0.005)$ \\
\hline
\end{tabular}

* Using Full Sample measure from 1990 Census

Notes: See Table 5 Notes 
Appendix Table B1, cont

\begin{tabular}{|c|c|c|c|}
\hline & \multicolumn{3}{|c|}{ IQR } \\
\hline & 1990 Census & 2000 Census & 2000 Census * \\
\hline Full Sample CV* Mig10*I1 & $0.180(0.004)$ & $0.175(0.004)$ & $0.134(0.004)$ \\
\hline Full Sample CV* Mig10*I2 & $-0.102(0.004)$ & $-0.129(0.004)$ & $-0.095(0.004)$ \\
\hline Full Sample CV* Mig10*I3 & $-0.115(0.004)$ & $-0.104(0.004)$ & $-0.096(0.004)$ \\
\hline Full Sample CV* Mig10*I4 & $-0.060(0.004)$ & $-0.044(0.004)$ & $-0.045(0.004)$ \\
\hline Full Sample CV* Mig10*I5 & $0.097(0.004)$ & $0.101(0.004)$ & $0.102(0.004)$ \\
\hline Full Sample CV* Mig5*I1 & $0.200(0.004)$ & $0.175(0.004)$ & $0.131(0.004)$ \\
\hline Full Sample CV* Mig5*I2 & $-0.140(0.004)$ & $-0.145(0.004)$ & $-0.112(0.004)$ \\
\hline Full Sample CV* Mig5*I3 & $-0.125(0.004)$ & $-0.098(0.004)$ & $-0.088(0.004)$ \\
\hline Full Sample CV* Mig5*I4 & $-0.047(0.004)$ & $-0.031(0.004)$ & $-0.031(0.004)$ \\
\hline Full Sample CV* Mig5*I5 & $0.112(0.004)$ & $0.100(0.004)$ & $0.101(0.004)$ \\
\hline Full Sample CV* Mig1*I1 & $0.190(0.004)$ & $0.167(0.004)$ & $0.120(0.004)$ \\
\hline Full Sample CV* Mig1*I2 & $-0.153(0.004)$ & $-0.157(0.004)$ & $-0.125(0.004)$ \\
\hline Full Sample CV* Mig1*I3 & $-0.097(0.004)$ & $-0.075(0.004)$ & $-0.066(0.004)$ \\
\hline Full Sample CV* Mig1*I4 & $-0.026(0.004)$ & $-0.019(0.004)$ & $-0.016(0.004)$ \\
\hline Full Sample CV* Mig1*I5 & $0.086(0.004)$ & $0.085(0.004)$ & $0.086(0.004)$ \\
\hline
\end{tabular}

* Using Full Sample measure from 1990 Census

Notes: See Table 5 Notes 
Appendix Table B2: Table 6 extension with additional income dispersion measures

\begin{tabular}{|c|c|c|c|c|}
\hline & $\begin{array}{l}\text { Interactions with } \\
\text { Negative Trend } \\
\text { Identifier }\end{array}$ & $\begin{array}{l}\text { Interactions with } \\
\text { Positive Trend } \\
\text { Identifier }\end{array}$ & $\begin{array}{l}\text { Interactions with } \\
\text { Negative Trend } \\
\text { Identifier }\end{array}$ & $\begin{array}{l}\text { Interactions with } \\
\text { Positive Trend } \\
\text { Identifier }\end{array}$ \\
\hline \multicolumn{5}{|l|}{1990} \\
\hline & \multicolumn{2}{|c|}{$\mathbf{R}$} & \multicolumn{2}{|c|}{ MM } \\
\hline Full SampleCV*Mig10 & $\begin{array}{l}0.040 \\
(0.009)\end{array}$ & $\begin{array}{l}-0.078 \\
(0.010)\end{array}$ & $\begin{array}{l}-0.106 \\
(0.018)\end{array}$ & $\begin{array}{l}-0.545 \\
(0.017)\end{array}$ \\
\hline Full Sample CV*Mig5 & $\begin{array}{l}-0.094 \\
(0.013)\end{array}$ & $\begin{array}{l}0.002 \\
(0.014)\end{array}$ & $\begin{array}{l}-0.288 \\
(0.026)\end{array}$ & $\begin{array}{l}0.120 \\
(0.023)\end{array}$ \\
\hline Full Sample CV*Mig1 & $\begin{array}{l}-0.190 \\
(0.013)\end{array}$ & $\begin{array}{l}-0.046 \\
(0.014)\end{array}$ & $\begin{array}{l}-0.367 \\
(0.026)\end{array}$ & $\begin{array}{l}0.146 \\
(0.024)\end{array}$ \\
\hline 2000 & & & & \\
\hline Full SampleCV*Mig10 & $\begin{array}{l}0.030 \\
(0.009)\end{array}$ & $\begin{array}{l}-0.109 \\
(0.010)\end{array}$ & $\begin{array}{l}-0.003 \\
(0.016)\end{array}$ & $\begin{array}{l}-0.471 \\
(0.014)\end{array}$ \\
\hline Full Sample CV*Mig5 & $\begin{array}{l}-0.082 \\
(0.013)\end{array}$ & $\begin{array}{l}0.027 \\
(0.014)\end{array}$ & $\begin{array}{l}-0.256 \\
(0.022)\end{array}$ & $\begin{array}{l}0.175 \\
(0.020)\end{array}$ \\
\hline Full Sample CV*Mig1 & $\begin{array}{l}-0.177 \\
(0.013)\end{array}$ & $\begin{array}{l}0.004 \\
(0.014)\end{array}$ & $\begin{array}{l}-0.386 \\
(0.022)\end{array}$ & $\begin{array}{l}0.215 \\
(0.020)\end{array}$ \\
\hline 1990 & \multicolumn{2}{|c|}{ IQR } & & \\
\hline Full SampleCV*Mig10 & $\begin{array}{l}-0.318 \\
(0.009)\end{array}$ & $\begin{array}{l}-0.348 \\
(0.008)\end{array}$ & & \\
\hline Full Sample CV*Mig5 & $\begin{array}{l}0.036 \\
(0.009)\end{array}$ & $\begin{array}{l}0.032 \\
(0.010)\end{array}$ & & \\
\hline Full Sample CV*Mig1 & $\begin{array}{l}-0.060 \\
(0.009)\end{array}$ & $\begin{array}{l}-0.017 \\
(0.010)\end{array}$ & & \\
\hline $\begin{array}{l}2000 \\
\text { Full SampleCV*Mig10 }\end{array}$ & $\begin{array}{l}-0.221 \\
(0.008)\end{array}$ & $\begin{array}{l}-0.347 \\
(0.008)\end{array}$ & & \\
\hline Full Sample CV*Mig5 & $\begin{array}{l}0.022 \\
(0.009)\end{array}$ & $\begin{array}{c}0.026 \\
(0.010)\end{array}$ & & \\
\hline Full Sample CV*Mig1 & $\begin{array}{l}-0.073 \\
(0.009) \\
\end{array}$ & $\begin{array}{l}0.003 \\
(0.010)\end{array}$ & & \\
\hline
\end{tabular}



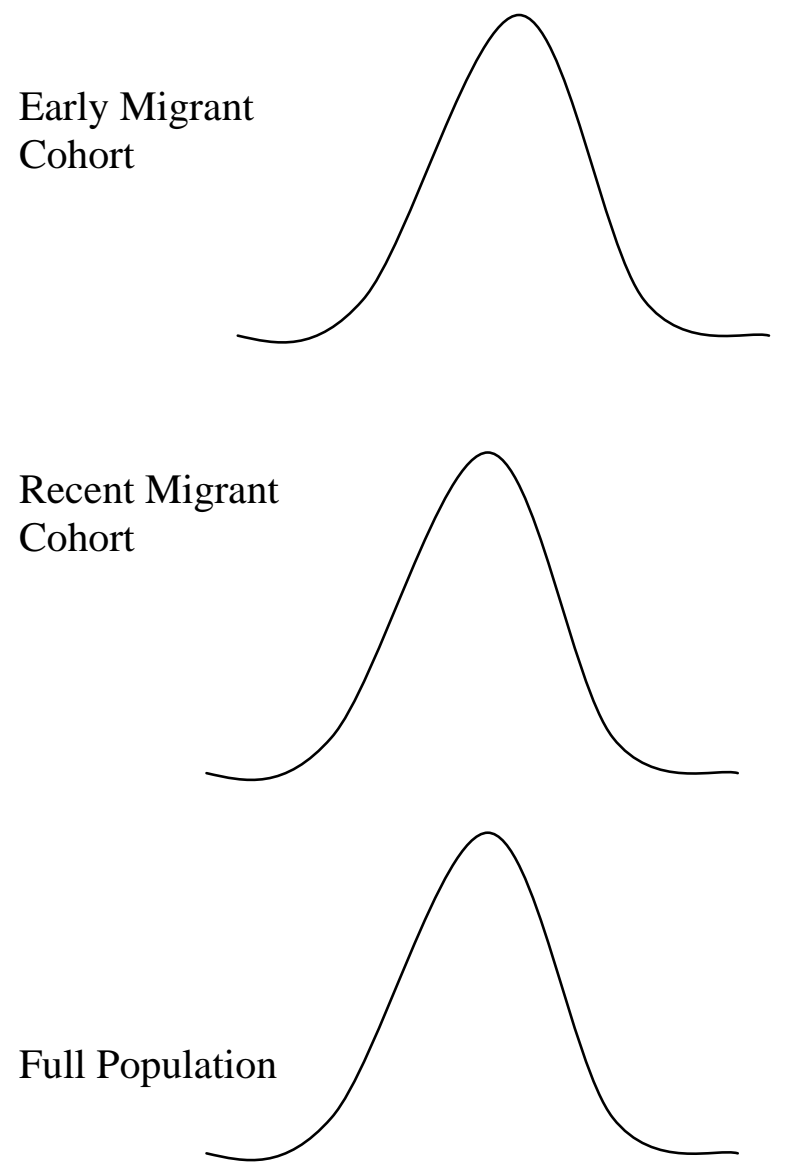

(a) Stable Neighborhood
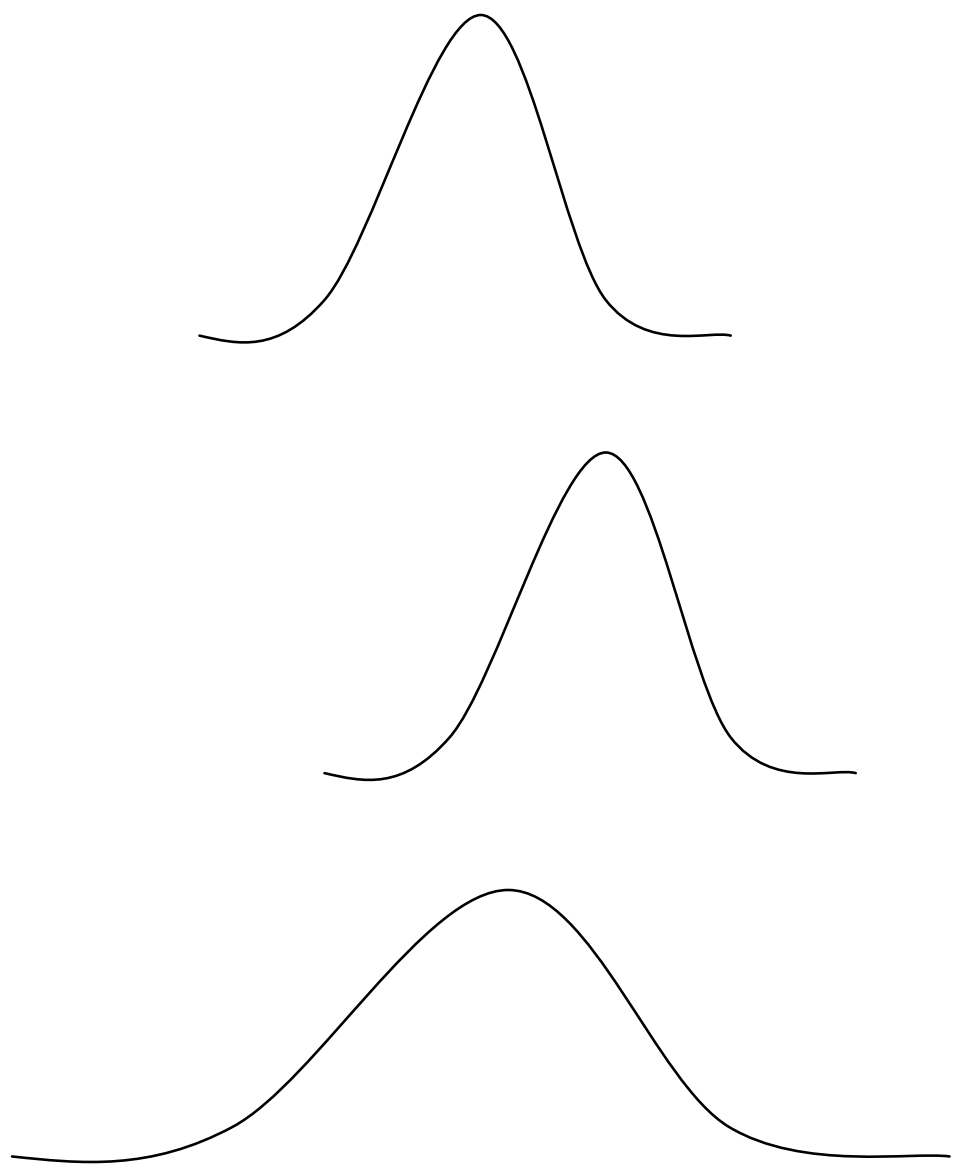

(b) Transitioning Neighborhood

Figure 1: Neighborhood Income Dispersion: Stable vs Transitioning Neighborhoods 
Table 1 -Correlations of Income Dispersion Measures

\begin{tabular}{llll} 
& $\mathrm{CV}$ & $\mathrm{R}$ & $\mathrm{MM}$ \\
\hline 1990 & 0.772 & & \\
$\mathrm{R}$ & 0.685 & 0.673 & 0.721 \\
$\mathrm{MM}$ & 0.369 & 0.379 & \\
$\mathrm{IQR}$ & & & \\
2000 & 0.795 & & \\
$\mathrm{R}$ & 0.683 & 0.707 & 0.713 \\
$\mathrm{MM}$ & 0.304 & 0.356 & \\
IQR & & & \\
\hline
\end{tabular}

Notes: Sample is 11, 879 central city census tracts in 72 most populous CMSA's in 1990. The income dispersion measures: CV (coefficient of variation), $\mathrm{R}$ (ratio of standard deviation to metro-area standard deviation), MM (ratio of mean to median), and IQR (ratio of interquartile range to median), are calculated for each tract in both the 1990 and 2000 Census. 
Table 2- Tract Characteristics Associated with Higher Coefficient of Variation in Household Income

\begin{tabular}{llll} 
& 1990 & 2000 & 2000 \\
\hline \%Black & 0.413 & 0.612 & 0.599 \\
\% Hispanic & $(0.041)$ & $(0.048)$ & $(0.049)$ \\
& -0.311 & -0.132 & -0.109 \\
\% HS Grad & $(0.088)$ & $(0.102)$ & $(0.102)$ \\
& -1.41 & -2.72 & -2.56 \\
\% College Grad & $(0.107)$ & $(0.148)$ & $(0.152)$ \\
\%<30 yrs old & 2.21 & 0.113 & -.183 \\
& $(0.107)$ & $(0.142)$ & $(0.143)$ \\
\%30-39 years old & 0.460 & 2.32 & 2.25 \\
\%40-49 years old & $(0.236)$ & $(0.272)$ & $(0.272)$ \\
\% 60+years old & -1.35 & 0.086 & -0.040 \\
& $(0.294)$ & $(0.354)$ & $(0.356)$ \\
Median Income & -0.177 & 1.60 & 1.75 \\
Income Change & $(0.350)$ & $(0.418)$ & $(0.419)$ \\
1990-2000*Positive & $(0.199$ & 1.43 & 1.43 \\
Change & & $(0.262)$ & $(0.262)$ \\
Income Change & & -0.002 & -0.016 \\
1990-2000*Negative & & $(0.012)$ & $(0.013)$ \\
Change & & & 0.098 \\
\hline N & & & $(0.030)$ \\
\hline
\end{tabular}

Notes: Sample is 11, 879 central city census tracts in 72 most populous CMSA's in 1990. Dependent variable is the tract-level coefficient of variation for household income. 
Table 3: Mean Tract Income Distribution Statistics

\begin{tabular}{lll} 
& 1990 & 2000 \\
\hline $\begin{array}{lll}\text { I1: \% households<50\% Metro- } \\
\text { Area Median Income }\end{array}$ & $\begin{array}{l}0.331 \\
(0.177)\end{array}$ & $\begin{array}{l}0.348 \\
(0.166)\end{array}$ \\
$\begin{array}{lll}\text { I2: \% households 50-100\% } \\
\text { Metro-Area Median Income }\end{array}$ & $\begin{array}{l}0.267 \\
(0.074\end{array}$ & $\begin{array}{l}0.278 \\
(0.070)\end{array}$ \\
I3: \% households 100-150\% & 0.180 & 0.166 \\
Metro-Area Median Income & $(0.064)$ & $(0.058)$ \\
& & \\
I4: \% households 150-200\% & 0.099 & 0.089 \\
Metro-Area Median Income & $(0.054)$ & $(0.048)$ \\
& & \\
I5: \% households> 200\% Metro- & 0.123 & 0.119 \\
Area Median Income & $(0.120)$ & $(0.114)$ \\
\hline N & 11,879 & 11,879 \\
\hline
\end{tabular}

Notes: Sample of census tracts is the same as described in notes of Table 1.

Table reports the mean fraction of households in a tract that fall in each of the 5 income categories. 
Table 4-Income Dispersion by Migrant Cohort

\begin{tabular}{|c|c|c|c|c|}
\hline & \multirow[b]{2}{*}{$\mathrm{CV}$} & \multicolumn{3}{|c|}{ Income Dispersion Measure (IDM)= } \\
\hline & & $\mathrm{R}$ & MM & IQR \\
\hline \multicolumn{5}{|l|}{1990 Census } \\
\hline Full Sample IDM * Mig10 & $0.518(0.007)$ & $0.876(0.008)$ & $1.03(0.014)$ & $0.963(0.019)$ \\
\hline Full Sample IDM * Mig5 & $0.589(0.007)$ & $0.844(0.008)$ & $0.957(0.014)$ & $0.994(0.019)$ \\
\hline Full Sample IDM * Mig1 & $0.465(0.007)$ & $0.576(0.008)$ & $0.817(0.014)$ & $0.891(0.019)$ \\
\hline \multicolumn{5}{|l|}{2000 Census } \\
\hline Full Sample IDM * Mig10 & $0.417(0.008)$ & $0.772(0.009)$ & $0.976(0.017)$ & $0.955(0.019)$ \\
\hline Full Sample IDM * Mig5 & $0.548(0.008)$ & $0.771(0.009)$ & $0.854(0.017)$ & $0.904(0.019)$ \\
\hline Full Sample IDM * Mig1 & $0.475(0.008)$ & $0.650(0.009)$ & $0.958(0.017)$ & $0.959(0.019)$ \\
\hline \multicolumn{5}{|l|}{$\begin{array}{l}2000 \text { Census using Full } \\
\text { Sample IDM calculated } \\
\text { from } 1990 \text { Census }\end{array}$} \\
\hline Full Sample IDM * Mig10 & $0.244(0.010)$ & $0.427(0.010)$ & $0.674(0.020)$ & $0.695(0.020)$ \\
\hline Full Sample IDM * Mig5 & $0.271(0.010)$ & $0.422(0.010)$ & $0.587(0.020)$ & $0.601(0.020)$ \\
\hline Full Sample IDM * Mig1 & $0.270(0.010)$ & $0.351(0.010)$ & $0.653(0.020)$ & $0.668(0.020)$ \\
\hline
\end{tabular}

Notes: Sample and income dispersion measures described in notes of Table 1. All regressions use the same sample of 11,879 census tracts. Table reports coefficient estimates from estimation of equation (1) using the 1990 Census and the 2000 Census. The dependent variable is the income dispersion measure for a particular migrant cohort. The table reports coefficient estimates on the interactions of the migrant cohort indicators with the income dispersion measure calculated on the full sample of households in the tract. In the bottom panel, the 2000 regression is re-estimated replacing the full-sample dispersion measure with one calculated for the same tract using the 1990 Census. All regressions control for tract median income and CMSA fixedeffects. 
Table 5- Income Distribution by Migrant Cohort

\begin{tabular}{|c|c|c|c|}
\hline & 1990 Census & 2000 Census & $\begin{array}{l}2000 \text { Census with } \\
\text { Full Sample CV } \\
\text { from } 1990 \text { Census }\end{array}$ \\
\hline Full Sample CV* Mig10*I1 & $0.025(0.001)$ & $0.025(0.001)$ & $0.021(0.001)$ \\
\hline Full Sample CV* Mig10*I2 & $-0.014(0.001)$ & $-0.013(0.001)$ & $-0.018(0.001)$ \\
\hline Full Sample CV* Mig10*I3 & $-0.023(0.001)$ & $-0.016(0.001)$ & $-0.018(0.001)$ \\
\hline Full Sample CV* Mig10*I4 & $-0.011(0.001)$ & $-0.010(0.001)$ & $-0.008(0.001)$ \\
\hline Full Sample CV* Mig10*I5 & $0.024(0.001)$ & $0.015(0.001)$ & $0.023(0.001)$ \\
\hline Full Sample CV* Mig5*I1 & $0.026(0.001)$ & $0.024(0.001)$ & $0.015(0.001)$ \\
\hline Full Sample CV* Mig5*I2 & $-0.019(0.001)$ & $-0.016(0.001)$ & $-0.018(0.001)$ \\
\hline Full Sample CV* Mig5*I3 & $-0.021(0.001)$ & $-0.016(0.001)$ & $-0.015(0.001)$ \\
\hline Full Sample CV* Mig5*I4 & $-0.009(0.001)$ & $-0.007(0.001)$ & $-0.005(0.001)$ \\
\hline Full Sample CV* Mig5*I5 & $0.023(0.001)$ & $0.015(0.001)$ & $0.023(0.001)$ \\
\hline Full Sample CV* Mig1*I1 & $0.023(0.001)$ & $0.025(0.001)$ & $0.021(0.001)$ \\
\hline Full Sample CV* Mig1*I2 & $-0.014(0.001)$ & $-0.013(0.001)$ & $-0.018(0.001)$ \\
\hline Full Sample CV* Mig1*I3 & $-0.023(0.001)$ & $-0.016(0.001)$ & $-0.018(0.001)$ \\
\hline Full Sample CV* Mig1*I4 & $-0.011(0.001)$ & $-0.010(0.001)$ & $-0.008(0.001)$ \\
\hline Full Sample CV* Mig1*I5 & $0.024(0.001)$ & $0.015(0.001)$ & $0.023(0.001)$ \\
\hline
\end{tabular}

Notes: All regressions use the same sample of 11,879 census tracts discussed in notes of Table 1. Table 5 reports coefficient estimates from estimation of equation (2) using the 1990 Census and the 2000 Census. The dependent variable is the fraction of households in a migrant cohort who are in a given income class. The table reports coefficient estimates on the triple interactions of the migrant cohort indicators with the income class indicators with the coefficient of variation calculated on the full sample of households in the tract. In the bottom panel, the 2000 regression 
is re-estimated replacing the full-sample coefficient of variation with one calculated for the same tract using the 1990 Census. All regressions control for tract median income and CMSA fixedeffects. 
Table 6- Income Dispersion and Neighborhood Income Transitions

\begin{tabular}{lll} 
& $\begin{array}{l}\text { Interactions with } \\
\text { Negative Trend } \\
\text { Identifier }\end{array}$ & $\begin{array}{l}\text { Interactions with } \\
\text { Positive Trend } \\
\text { Identifier }\end{array}$ \\
\hline 1990 & & \\
Full SampleCV*Mig10 & -0.010 & -0.056 \\
& $(0.004)$ & $(0.004)$ \\
Full Sample CV*Mig5 & -0.028 & 0.013 \\
& $(0.005)$ & $(0.005)$ \\
Full Sample CV*Mig1 & -0.040 & 0.012 \\
& $(0.005)$ & $(0.005)$ \\
2000 & & \\
Full SampleCV*Mig10 & -0.021 & -0.049 \\
Full Sample CV*Mig5 & $(0.003)$ & $(0.003)$ \\
& -0.014 & 0.012 \\
Full Sample CV*Mig1 & $(0.005)$ & $(0.004)$ \\
& -0.018 & 0.020 \\
& $(0.005)$ & $(0.004)$ \\
\hline
\end{tabular}

Notes: Both regressions use the same sample of 11,879 census tracts described in the notes of Table 1. Table 6 reports coefficient estimates from estimation of equation (3) using the 1990 Census and the 2000 Census. The dependent variable is the median household income for a particular migrant cohort. The table reports coefficient estimates on the triple interactions of the migrant cohort indicators with the coefficient of variation calculated on the full sample of households in the tract with an indicator for positive or negative income trend. The positive and negative trend indicators are described in more detail in the text on p.19. All regressions control for tract median income and CMSA fixed-effects. 
Table 7- Age and Income Characteristics of In-Migrants by Neighborhood Income Dispersion

\begin{tabular}{|c|c|c|c|c|}
\hline & \multicolumn{2}{|c|}{1990} & \multicolumn{2}{|c|}{2000} \\
\hline & $\begin{array}{l}\text { Moved in Last } \\
10 \text { years }\end{array}$ & $\begin{array}{l}\text { Moved in Last } \\
\text { Year }\end{array}$ & $\begin{array}{l}\text { Moved in Last } \\
10 \text { years }\end{array}$ & $\begin{array}{l}\text { Moved in Last } \\
\text { Year }\end{array}$ \\
\hline Low-Income*Young & $\begin{array}{l}0.086 \\
(0.009)\end{array}$ & $\begin{array}{l}0.086 \\
(0.010)\end{array}$ & $\begin{array}{l}0.083 \\
(0.011)\end{array}$ & $\begin{array}{l}0.071 \\
(0.012)\end{array}$ \\
\hline $\begin{array}{l}\text { Low-Income*Prime } \\
\text { Omitted Reference Grou }\end{array}$ & & & & \\
\hline Low-Income*Older & $\begin{array}{l}0.021 \\
(0.010)\end{array}$ & $\begin{array}{l}0.008 \\
(0.013)\end{array}$ & $\begin{array}{l}-0.002 \\
(0.011)\end{array}$ & $\begin{array}{l}-0.001 \\
(0.014)\end{array}$ \\
\hline Middle-Income*Young & $\begin{array}{l}-0.103 \\
(0.008)\end{array}$ & $\begin{array}{l}-0.075 \\
(0.008)\end{array}$ & $\begin{array}{l}-0.102 \\
(0.008)\end{array}$ & $\begin{array}{l}-0.090 \\
(0.009)\end{array}$ \\
\hline Middle-Income*Prime & $\begin{array}{l}-0.128 \\
(0.006)\end{array}$ & $\begin{array}{l}-0.089 \\
(0.006)\end{array}$ & $\begin{array}{l}-0.163 \\
(0.006)\end{array}$ & $\begin{array}{l}-0.128 \\
(0.007)\end{array}$ \\
\hline Middle-Income*Older & $\begin{array}{l}-0.027 \\
(0.010)\end{array}$ & $\begin{array}{l}-0.023 \\
(0.013)\end{array}$ & $\begin{array}{l}-0.104 \\
(0.009)\end{array}$ & $\begin{array}{l}-0.087 \\
(0.012)\end{array}$ \\
\hline High-Income*Young & $\begin{array}{l}0.298 \\
(0.022)\end{array}$ & $\begin{array}{l}0.335 \\
(0.025)\end{array}$ & $\begin{array}{l}0.070 \\
(0.012)\end{array}$ & $\begin{array}{l}0.120 \\
(0.014)\end{array}$ \\
\hline High-Income*Prime & $\begin{array}{l}0.319 \\
(0.015)\end{array}$ & $\begin{array}{l}0.369 \\
(0.017)\end{array}$ & $\begin{array}{l}0.063 \\
(0.006)\end{array}$ & $\begin{array}{l}0.132 \\
(0.010)\end{array}$ \\
\hline High-Income*Older & $\begin{array}{l}0.470 \\
(0.031)\end{array}$ & $\begin{array}{l}0.425 \\
(0.038)\end{array}$ & $\begin{array}{l}0.177 \\
(0.013)\end{array}$ & $\begin{array}{l}0.198 \\
(0.021)\end{array}$ \\
\hline $\mathrm{N}$ & $1,779,059$ & 631,825 & $2,072,846$ & 690,400 \\
\hline
\end{tabular}

Notes: Column 1 and 3 samples are all householders, in the sample of 11,879 tracts analyzed in Tables 1-6, who moved into their current residence in the past 10 years. Column 2 and 4 samples are further restricted to those who moved into their current residence in the past year. Table 7 reports coefficient estimates from equation (4). Dependent variable is tract coefficient of variation. Table reports coefficient estimates for indicators for 9 age- income categories, as described on p.20-21 of the text . All regressions include controls for race, education, presence of children, tract median income and CMSA fixed-effects. Standard errors clustered at the tract level. 
Table 8- Age, Income and Education Characteristics of In-Migrants by Neighborhood Income Dispersion

\begin{tabular}{|c|c|c|c|c|}
\hline & \multicolumn{2}{|c|}{1990} & \multicolumn{2}{|c|}{2000} \\
\hline & $\begin{array}{l}\text { Moved in Last } \\
10 \text { years }\end{array}$ & $\begin{array}{l}\text { Moved in Last } \\
\text { Year }\end{array}$ & $\begin{array}{l}\text { Moved in Last } \\
10 \text { years }\end{array}$ & $\begin{array}{l}\text { Moved in Last } \\
\text { Year }\end{array}$ \\
\hline Low-Income*Young $*<$ HS & $\begin{array}{l}0.089 \\
(0.021)\end{array}$ & $\begin{array}{l}0.092 \\
(0.023)\end{array}$ & $\begin{array}{l}0.087 \\
(0.023)\end{array}$ & $\begin{array}{l}0.086 \\
(0.026)\end{array}$ \\
\hline Low-Income*Young*HS & $\begin{array}{l}0.113 \\
(0.026)\end{array}$ & $\begin{array}{l}0.153 \\
(0.029)\end{array}$ & $\begin{array}{l}0.054 \\
(0.028)\end{array}$ & $\begin{array}{l}0.090 \\
(0.033)\end{array}$ \\
\hline Low-Income*Young*College & $\begin{array}{l}0.440 \\
(0.049)\end{array}$ & $\begin{array}{l}0.469 \\
(0.048)\end{array}$ & $\begin{array}{l}0.276 \\
(0.041)\end{array}$ & $\begin{array}{l}0.302 \\
(0.043)\end{array}$ \\
\hline $\begin{array}{l}\text { Low-Income*Prime } *<\text { HS } \\
\text { Omitted Reference Group }\end{array}$ & & & & \\
\hline Low-Income*Prime*HS & $\begin{array}{l}0.055 \\
(0.023)\end{array}$ & $\begin{array}{l}0.086 \\
(0.025)\end{array}$ & $\begin{array}{l}-0.010 \\
(0.023)\end{array}$ & $\begin{array}{l}0.026 \\
(0.027)\end{array}$ \\
\hline Low-Income*Prime*College & $\begin{array}{l}0.308 \\
(0.036)\end{array}$ & $\begin{array}{l}0.346 \\
(0.037)\end{array}$ & $\begin{array}{l}0.151 \\
(0.034)\end{array}$ & $\begin{array}{l}0.189 \\
(0.037)\end{array}$ \\
\hline Low-Income*Older $*<$ HS & $\begin{array}{l}0.069 \\
(0.027)\end{array}$ & $\begin{array}{l}0.079 \\
(0.029)\end{array}$ & $\begin{array}{l}0.067 \\
(0.028)\end{array}$ & $\begin{array}{l}0.099 \\
(0.033)\end{array}$ \\
\hline Low-Income*Older*HS & $\begin{array}{l}0.134 \\
(0.037)\end{array}$ & $\begin{array}{l}0.150 \\
(0.039)\end{array}$ & $\begin{array}{l}0.017 \\
(0.029)\end{array}$ & $\begin{array}{l}0.054 \\
(0.032)\end{array}$ \\
\hline Low-Income*Older*College & $\begin{array}{l}0.330 \\
(0.046)\end{array}$ & $\begin{array}{l}0.320 \\
(0.055)\end{array}$ & $\begin{array}{l}0.217 \\
(0.041)\end{array}$ & $\begin{array}{l}0.243 \\
(0.047)\end{array}$ \\
\hline Middle-Income*Young* $<$ HS & $\begin{array}{l}-0.105 \\
(0.018)\end{array}$ & $\begin{array}{l}-0.067 \\
(0.021)\end{array}$ & $\begin{array}{l}-0.105 \\
(0.022)\end{array}$ & $\begin{array}{l}-0.070 \\
(0.025)\end{array}$ \\
\hline Middle-Income*Young*HS & $\begin{array}{l}-0.100 \\
(0.021)\end{array}$ & $\begin{array}{l}-0.044 \\
(0.023)\end{array}$ & $\begin{array}{l}-0.177 \\
(0.023)\end{array}$ & $\begin{array}{l}-0.129 \\
(0.025)\end{array}$ \\
\hline $\begin{array}{l}\text { Middle- } \\
\text { Income*Young*College }\end{array}$ & $\begin{array}{l}0.295 \\
(0.044)\end{array}$ & $\begin{array}{l}0.358 \\
(0.044)\end{array}$ & $\begin{array}{l}0.149 \\
(0.035)\end{array}$ & $\begin{array}{l}0.202 \\
(0.036)\end{array}$ \\
\hline Middle-Income*Prime ${ }^{*}<$ HS & $\begin{array}{l}-0.088 \\
(0.017)\end{array}$ & $\begin{array}{l}-0.041 \\
(0.020)\end{array}$ & $\begin{array}{l}-0.117 \\
(0.020)\end{array}$ & $\begin{array}{l}-0.063 \\
(0.023)\end{array}$ \\
\hline
\end{tabular}




\begin{tabular}{|c|c|c|c|c|}
\hline Middle-Income*Prime*HS & $\begin{array}{l}-0.077 \\
(0.022)\end{array}$ & $\begin{array}{l}-0.011 \\
(0.024)\end{array}$ & $\begin{array}{l}-0.190 \\
(0.022)\end{array}$ & $\begin{array}{l}-0.120 \\
(0.025)\end{array}$ \\
\hline $\begin{array}{l}\text { Middle- } \\
\text { Income*Prime*College }\end{array}$ & $\begin{array}{l}0.218 \\
(0.032)\end{array}$ & $\begin{array}{l}0.293 \\
(0.032)\end{array}$ & $\begin{array}{l}0.044 \\
(0.029)\end{array}$ & $\begin{array}{l}0.123 \\
(0.032)\end{array}$ \\
\hline Middle-Income*Older* $<$ HS & $\begin{array}{l}-0.055 \\
(0.029)\end{array}$ & $\begin{array}{l}-0.009 \\
(0.032)\end{array}$ & $\begin{array}{l}-0.127 \\
(0.025)\end{array}$ & $\begin{array}{l}-0.090 \\
(0.029)\end{array}$ \\
\hline Middle-Income*Older*HS & $\begin{array}{l}0.100 \\
(0.033)\end{array}$ & $\begin{array}{l}0.116 \\
(0.039)\end{array}$ & $\begin{array}{l}-0.091 \\
(0.006)\end{array}$ & $\begin{array}{l}-0.035 \\
(0.030)\end{array}$ \\
\hline Middle-Income*Older*College & $\begin{array}{l}0.363 \\
(0.043)\end{array}$ & $\begin{array}{l}0.392 \\
(0.049)\end{array}$ & $\begin{array}{l}0.141 \\
(0.034)\end{array}$ & $\begin{array}{l}0.200 \\
(0.039)\end{array}$ \\
\hline High-Income*Young $*<$ HS & $\begin{array}{l}0.158 \\
(0.056)\end{array}$ & $\begin{array}{l}0.309 \\
(0.087)\end{array}$ & $\begin{array}{l}0.076 \\
(0.037)\end{array}$ & $\begin{array}{l}0.180 \\
(0.054)\end{array}$ \\
\hline High-Income*Young*HS & $\begin{array}{l}0.253 \\
(0.042)\end{array}$ & $\begin{array}{l}0.324 \\
(0.047)\end{array}$ & $\begin{array}{l}-0.068 \\
(0.027)\end{array}$ & $\begin{array}{l}0.030 \\
(0.032)\end{array}$ \\
\hline High-Income*Young*College & $\begin{array}{l}0.845 \\
(0.056)\end{array}$ & $\begin{array}{l}0.910 \\
(0.062)\end{array}$ & $\begin{array}{l}0.409 \\
(0.037)\end{array}$ & $\begin{array}{l}0.484 \\
(0.038)\end{array}$ \\
\hline High-Income*Prime* $<$ HS & $\begin{array}{l}0.184 \\
(0.034)\end{array}$ & $\begin{array}{l}0.200 \\
(0.056)\end{array}$ & $\begin{array}{l}-0.025 \\
(0.024)\end{array}$ & $\begin{array}{l}0.076 \\
(0.035)\end{array}$ \\
\hline High-Income*Prime*HS & $\begin{array}{l}0.316 \\
(0.042)\end{array}$ & $\begin{array}{l}0.441 \\
(0.049)\end{array}$ & $\begin{array}{l}-0.047 \\
(0.027)\end{array}$ & $\begin{array}{l}0.067 \\
(0.031)\end{array}$ \\
\hline High-Income*Prime*College & $\begin{array}{l}0.756 \\
(0.047)\end{array}$ & $\begin{array}{l}0.830 \\
(0.046)\end{array}$ & $\begin{array}{l}0.373 \\
(0.034)\end{array}$ & $\begin{array}{l}0.480 \\
(0.039)\end{array}$ \\
\hline High-Income*Older $*<$ HS & $\begin{array}{l}0.319 \\
(0.061)\end{array}$ & $\begin{array}{l}0.242 \\
(0.108)\end{array}$ & $\begin{array}{l}0.067 \\
(0.036)\end{array}$ & $\begin{array}{l}0.070 \\
(0.060)\end{array}$ \\
\hline High-Income*Older*HS & $\begin{array}{l}0.658 \\
(0.063)\end{array}$ & $\begin{array}{l}0.656 \\
(0.081)\end{array}$ & $\begin{array}{l}0.162 \\
(0.035)\end{array}$ & $\begin{array}{l}0.241 \\
(0.042)\end{array}$ \\
\hline High-Income*Older*College & $\begin{array}{l}0.907 \\
(0.063)\end{array}$ & $\begin{array}{l}0.881 \\
(0.071)\end{array}$ & $\begin{array}{l}0.496 \\
(0.043)\end{array}$ & $\begin{array}{l}0.550 \\
(0.048)\end{array}$ \\
\hline $\mathrm{N}$ & $1,779,059$ & 631,825 & $2,072,846$ & 690,400 \\
\hline
\end{tabular}


Notes: Column 1 and 3 samples are all householders, in the sample of 11,879 tracts analyzed in Tables 1-6, who moved into their current residence in the past 10 years. Column 2 and 4 samples are further restricted to those who moved into their current residence in the past year. Table 8 reports coefficient estimates from equation (5). Dependent variable is tract coefficient of variation. Table reports coefficient estimates for indicators for 27 age- income-education categories as described on p.21 of the text. All regressions include controls for race, education, presence of children, tract median income and CMSA fixed-effects. Standard errors clustered at the tract level. 